\title{
Growth rates of North Sea macroalgae in relation to temperature, irradiance and photoperiod
}

\author{
M. D. Fortes ${ }^{1,2} \&$ K. Lüning ${ }^{2}$ \\ ${ }^{1}$ Marine Sciences Center, University of the Philippines; Quezon City, The Philippines, \\ ${ }^{2}$ Biologische Anstalt Helgoland (Meeresstation); D-2192 Helgoland, Federal Republic of \\ Germany
}

\begin{abstract}
Three eulittoral algae (Ulva lactuca, Porphyra umbilicalis, Chondrus crispus) and one sublittoral alga (Laminaria saccharina) from Helgoland (North Sea) were cultivated in a flowthrough system at different temperatures, irradiances and daylengths. In regard to temperature there was a broad optimum at $10-15^{\circ} \mathrm{C}$, except in $P$. umbilicalis, which grew fastest at $10^{\circ} \mathrm{C}$. A growth peak at this temperature was also found in four of 17 other North Sea macroalgae, for which the growth/temperature response was studied, whereas 13 of these species exhibited a growth optimum at $15^{\circ} \mathrm{C}$, or a broad optimum at $10-15^{\circ} \mathrm{C}$. Growth was light-saturated in $U$. lactuca, $L$. saccharina and $C$. crispus at photon flux densities above $70 \mu \mathrm{E} \mathrm{m}^{-2} \mathrm{~s}^{-1}$, but in $P$. umbilicalis above 30 $\mu \mathrm{E} \mathrm{m}^{-2} \mathrm{~s}^{-1}$. Growth rate did not decrease notably in the eulittoral species after one week in relatively strong light $\left(250 \mu \mathrm{E} \mathrm{m} \mathrm{m}^{-2} \mathrm{~s}^{-1}\right)$, but by about $50 \%$ in the case of the sublittoral $L$. saccharina, as compared with growth under weak light conditions $\left(30 \mu \mathrm{E} \mathrm{m}^{-2} \mathrm{~s}^{-1}\right)$. In contrast, chlorophyll content decreased in the sublittoral as well as in the eulittoral species, and the greatest change in pigment content occurred in the range $30-70 \mu \mathrm{E} \mathrm{m}^{-2} \mathrm{~s}^{-1}$. Growth rate increased continuously up to photoperiods of $24 \mathrm{~h}$ light per day in L. saccharina and C. crispus, whereas daylength saturation occurred at photoperiods of more than $16 \mathrm{~h}$ light per day in $U$. lactuca and $P$. umbilicalis.
\end{abstract}

\section{INTRODUCTION}

The geographical distribution of marine macroalgae has been correlated with their temperature requirements (Setchell, 1915, 1920), and, according to the recent reviews of van den Hoek $(1975,1979)$, the southern limits of many algal species in the North Atlantic can be characterized by summer isotherms. However, besides short-term experiments on temperature resistance performed by Biebl (e. g. 1958, 1962), not much experimental work has been done on this subject, especially not on the relationship between temperature and growth rate (see review by Gessner, 1970). The same is true for the dependence of growth rate on other factors, such as irradiance or photoperiod (see review by Lüning, 1980), and the reason for this lack of data obviously lies in the difficulties in handling larger algae. In the present study an attempt is made to fill this gap in the cases of four widely-distributed algal species, and to find out the growth/ temperature relationship for an additional 17 species, all occurring in the North Sea and adjacent waters. 


\section{MATERIALS AND METHODS}

The algae used in this study were collected in spring (March or April; for temperature experiments) or summer in the eulittoral or sublittoral at Helgoland, North Sea (Table 1). In the cases of Ulva lactuca and Porphyra umbilicalis disks of $2-5 \mathrm{~cm}$ in diameter were pinned at the tips of $2-\mathrm{cm}$ long polyethylene rods held firmly in the holes of white ceramic desiccator plates. Fronds of Laminaria saccharina (original length: $100-150 \mathrm{~cm}$, presumable age 1-2 years) were cut to $30 \mathrm{~cm}$ (with $3-5 \mathrm{~cm}$ long stipes) and a 4-mm diameter hole was punched at the middle of each, $5 \mathrm{~cm}$ above the meristematic transition zone between frond and stipe. For Chondrus crispus 2-cm-long apices were used. In the other 17 species investigated whole thalli (Phyllophora membranifolia), or portions of 2-cm length (Polysiphonia urceolata) or $5-\mathrm{cm}$ length (all others) were used. In Delesseria sanguinea and Desmarestia aculeata growth was followed in young shoots which had developed in spring from the perennial thallus. The young shoots were left in contact with the perennial thallus in these cases. In all species 10 individuals were used for each experimental condition.

Growth was determined in terms of area, length, or cell number, as indicated in Table 1. Area was measured using an automat area meter (LI-COR, Nebraska; type LI-

Table. 1. Species investigated with habitat and parameters used for determination of growth rate

\begin{tabular}{|c|c|c|}
\hline Species & Parameter & $\begin{array}{l}\text { Temperature } \\
\text { response in Fig. }\end{array}$ \\
\hline \multicolumn{3}{|l|}{$\begin{array}{l}\text { Eulittoral algae } \\
\text { Chlorophyceae }\end{array}$} \\
\hline Acrosiphonia arcta & length & 1 \\
\hline Enteromorpha sp. & length & 2 \\
\hline Ulva lactuca & area & 2 \\
\hline \multicolumn{3}{|l|}{ Phaeophyceae } \\
\hline Ascophyllum nodosum & length & 3 \\
\hline Fucus serratus & length & 3 \\
\hline Fucus spiralis & length & 3 \\
\hline Fucus vesiculosus & length & 3 \\
\hline Petalonia fascia & length & 4 \\
\hline Punctaria plantaginea & area & 4 \\
\hline \multicolumn{3}{|l|}{ Rhodophyceae } \\
\hline Chondrus crispus & area & 5 \\
\hline Dumontia incrassata & length & 5 \\
\hline Plumaria elegans & no. of cells & 5 \\
\hline Porphyra umbilicalis & area & 1 \\
\hline \multicolumn{3}{|l|}{ Sublittoralalgae } \\
\hline Desmarestia aculeata & length & 1 \\
\hline Laminaria saccharina & length & 4 \\
\hline \multicolumn{3}{|l|}{ Rhodophyceae } \\
\hline Ceramium rubrum & length & 6 \\
\hline Cystoclonium purpureum & length & 5 \\
\hline Membranoptera alata & length & 6 \\
\hline Phyllophora pseudoceranoides & area & 1 \\
\hline Polysiphonia urceolata & length & 1 \\
\hline
\end{tabular}


3100 ) adjusted to $0.1-\mathrm{mm}^{2}$ resolution. Growth rate is expressed in this paper as specific growth rate (in percentage increase in the parameter per day; Evans 1972). Concentrations of chlorophylls $a$ and $b$ were determined according to Arnon (1949) and chlorophyll $c$ according to Wasley et al. (1970). Each chlorophyll value is based on the determination of 10 disks (15 $\mathrm{mm}$ of diameter) cut from the experimental individuals.

The algae were cultivated for one week in Plexiglas-covered polyester tanks (60 1 volume; $10 \mathrm{~cm}$ deep, $150 \times 50 \mathrm{~cm}$ ) containing enriched seawater (PES; according to Provasoli, 1968; however, only $1 / 3$ of the concentration as indicated in the original recipe). The $1 / 3$ PES, which was prepared automatically by pumping the enrichment into filtered seawater (Seitz asbestos filter K 5, combined with Millipore membrane filters, $0.45 \mu \mathrm{m}$ ) was automatically distributed into each of 6 culture tanks at the rate of $1 \mathrm{l} \mathrm{h}^{-1}$ corresponding to a turnover rate of 2.5 days. The culture tanks were aerated, and rotary pumps (Eheim, West Germany; type 1036) facilitated continuous water agitation in order to keep the algae in suspension as well as to allow mixing and gas exchange. Within the tanks the experimental individuals were held flat on plastic screens by 3-mm-wide polyethylene rods to insure that the flat thalli were horizontally exposed to the incident light. The algae were pretreated in the experimental conditions for approximately $24 \mathrm{~h}$.

The tanks were illuminated from above by means of cool white fluorescent lamps (Osram $65 \mathrm{~W} / 19$ ). In the temperature and irradiance experiments a 16:8 LD regime was used. Daylength experiments were run at a temperature of $10^{\circ} \mathrm{C}$. Photon flux densities were measured by means of a quantameter (LI-COR, Nebraska) and were adjusted to the desired levels by grey Plexiglas filters (Röhm and Haass, No. 800). For rough conversion of light-measuring units the following relation may be used for the lamps employed (Lüning, 1980):

$$
5 \mu \mathrm{E} \mathrm{m} \mathrm{m}^{-2} \mathrm{~s}^{-1} \sim 1 \mathrm{~W} \mathrm{~m}^{-2} \sim 250 \text { lux. }
$$

\section{RESULTS}

\section{Effects of temperature}

On the basis of their growth vs. temperature curves, the species investigated can be subdivided basically into two groups: (a) species with a temperature optimum at $10{ }^{\circ} \mathrm{C}$ (Acrosiphonia arcta, Desmarestia aculeata, Phyllophora pseudoceranoides, Polysiphonia urceolata, Porphyra umbilicalis; Fig. 1), and (b) species with an optimum at $15^{\circ} \mathrm{C}$ (Fucus spp., Ascophyllum nodosum, Fig. 3; Laminaria saccharina, Fig. 4; Plumaria elegans, Fig. 5. Ceramium rubrum, Fig. 6), or with a broad optimum at $10-15^{\circ} \mathrm{C}$ (all others; Figs. 4-6). In none of the species investigated did a temperature peak lower than $10^{\circ} \mathrm{C}$ or higher than $15^{\circ} \mathrm{C}$ occur.

\section{Effects of irradiance}

All species investigated exhibited a linear relationship between growth rate and irradiance up to photon flux densities of $20-30 \mu \mathrm{E} \mathrm{m}^{-2} \mathrm{~s}^{-1}$ (Fig. 7). Saturation of growth occurred at photon flux densities above $70 \mu \mathrm{E} \mathrm{m}^{-2} \mathrm{~s}^{-1}$ in Ulva lactuca, Laminaria saccharina and Chondrus crispus, or at $30 \mu \mathrm{E} \mathrm{m}^{-2} \mathrm{~s}^{-1}$ in Porphyra umbilicalis. 


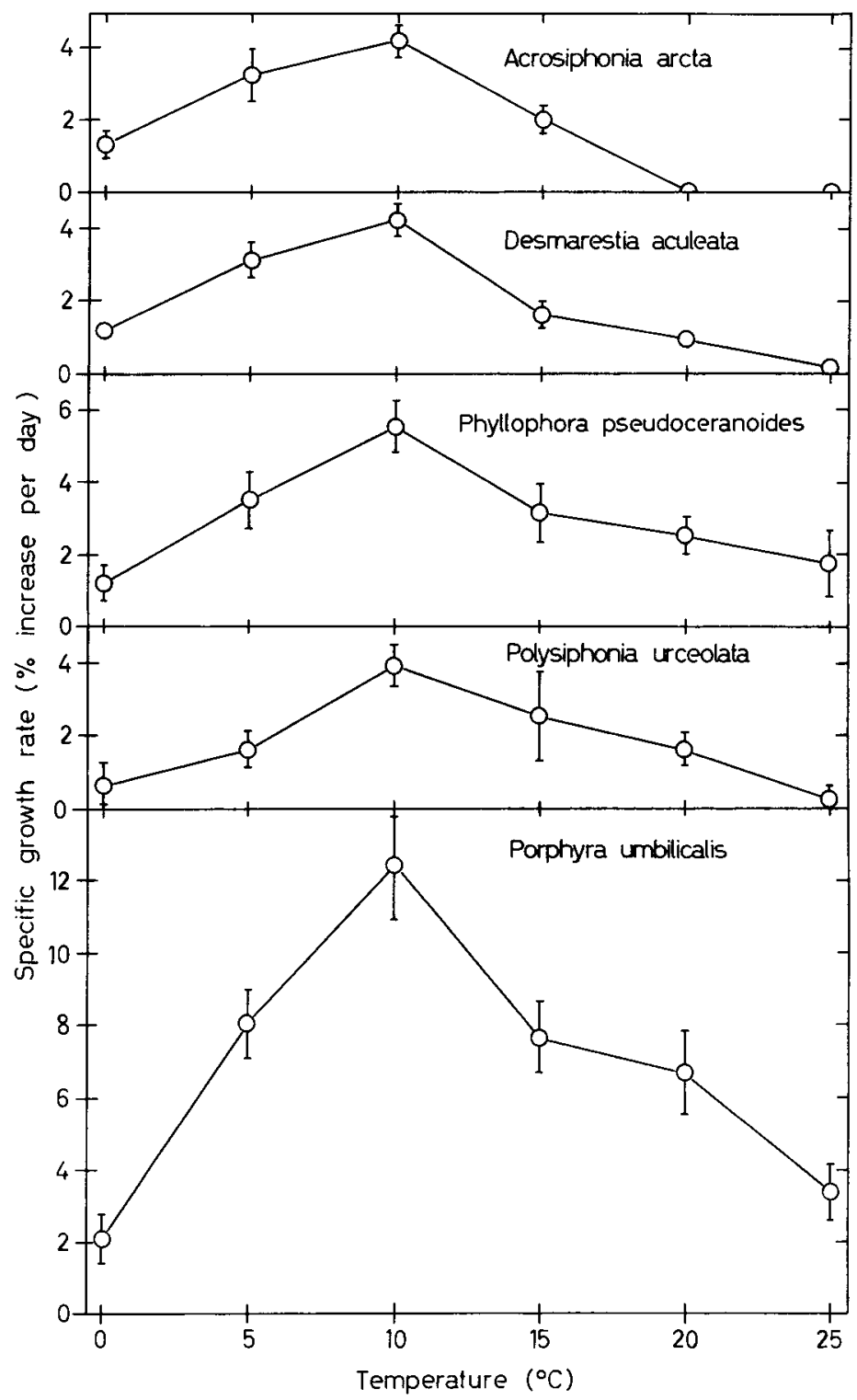

Fig. 1. Algal species with temperature optimum at $10^{\circ} \mathrm{C}$ : growth vs. temperature plot. For all figures: Duration of experiment was one week. Vertical bars indicate confidence limits $(n=10)$

At the highest photon flux density used $\left(250 \mu \mathrm{E} \mathrm{m}^{-2} \mathrm{~s}^{-1}\right)$ the growth rate of Laminaria saccharina was $50 \%$ lower than at the optimum photon flux density of $110 \mu \mathrm{E} \mathrm{m}^{-2} \mathrm{~s}^{-1}$ (Fig. 7). No or almost no decline of growth rate at the highest photon flux density used occurred in the other three species. 


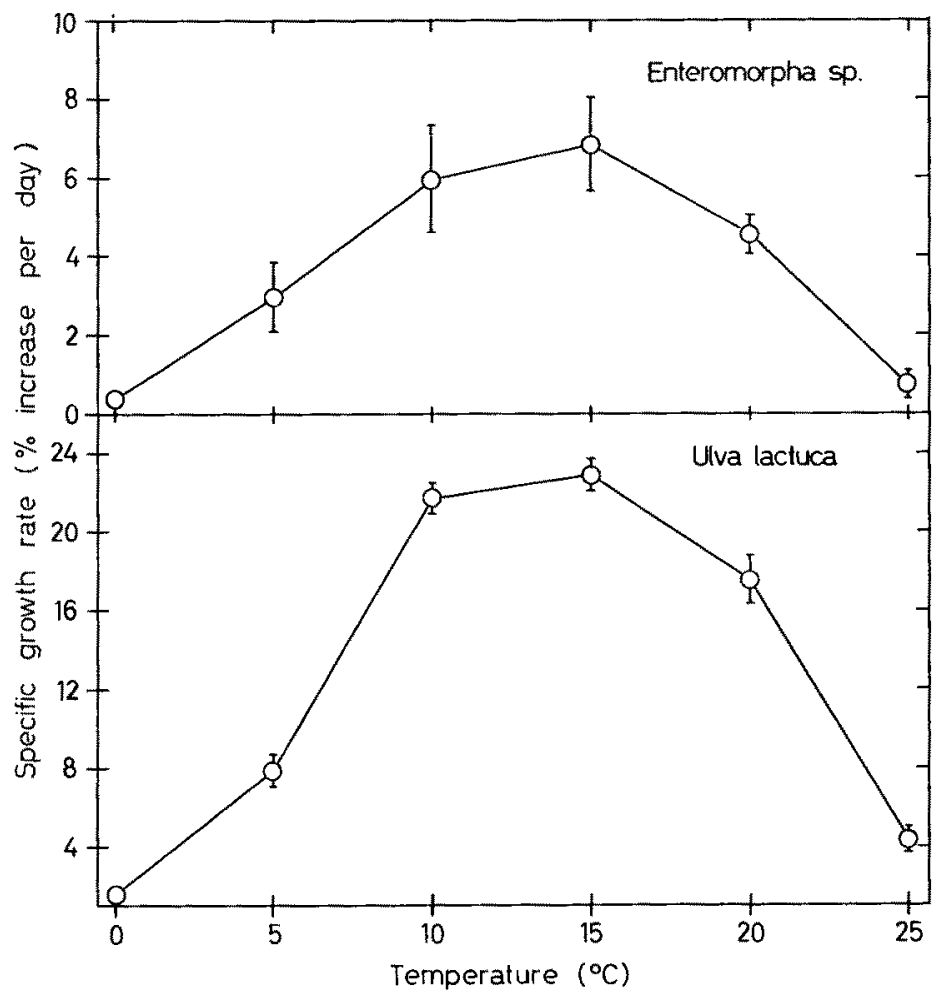

Fig. 2. Green algae from the eulittoral: growth vs. temperature plot

Chlorophyll concentrations (Chondrus crispus was not investigated for pigments) decreased after cultivation for one week at photon flux densities higher than $30 \mu \mathrm{E} \mathrm{m}^{-2} \mathrm{~s}^{-1}$ (Fig. 8). After one week at $250 \mu \mathrm{E} \mathrm{cm}^{-2} \mathrm{~s}^{-1}$ the chlorophyll a content of the experimental algae had been reduced to $64 \%$ (Laminaria saccharina), $54 \%$ (Porphyra umbilicalis) and $43 \%$ (Ulva lactuca) of the values obtained, again after one week, at the lowest

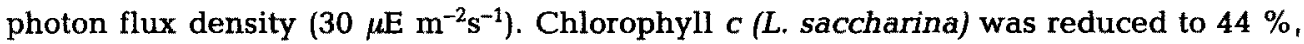
and chlorophyll $b$ (U. lactuca) to $51 \%$ under the same conditions. In continuous darkness a slight decrease in chlorophyll a concentration was noticed after one week in $L$. saccharina and $U$. lactuca, whereas $P$. umbilicalis exhibited a slight increase (Fig. 8). In contrast to the other two species, $U$. lactuca showed decreased chlorophyll levels under all experimental conditions after one week's cultivation.

\section{Effects of daylength}

As can be seen from Figure 9, the growth rate increased almost linearly with daylengths up to $24 \mathrm{~h}$ light per day in Chondrus crispus as well as in Laminaria saccharina, although the results for the latter species are somewhat erratic. In the other two species investigated the growth vs. daylength curves began to flatten out at daylengths greater than $16 \mathrm{~h}$ (Ulva lactuca, Porphyra umbilicalis). Growth rate in 


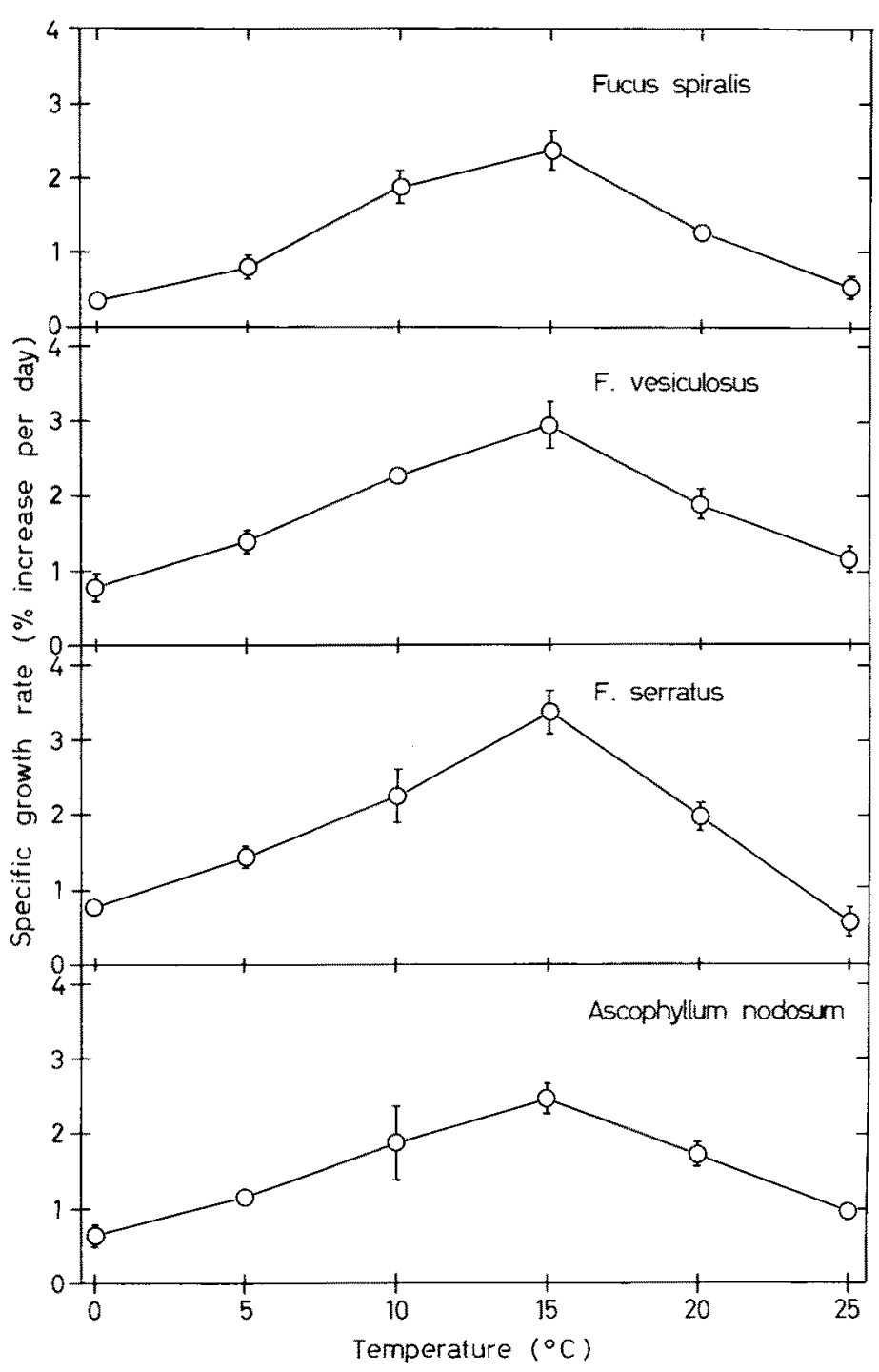

Fig. 3. Rockweeds from the eulittoral: growth vs. temperature plot

continuous darkness was zero ( $P$. umbilicalis) or rather low (specific growth rate in percent increase per day: 1.9 in C. crispus, 0.3 in $U$. lactuca and 0.2 in L. saccharina).

Chlorophyll concentrations did not appear to be materially affected by daylength and remained at $+/-20 \%$ compared with the chlorophyll content at the start of the experiment (Chrondrus crispus was not investigated for pigments). 


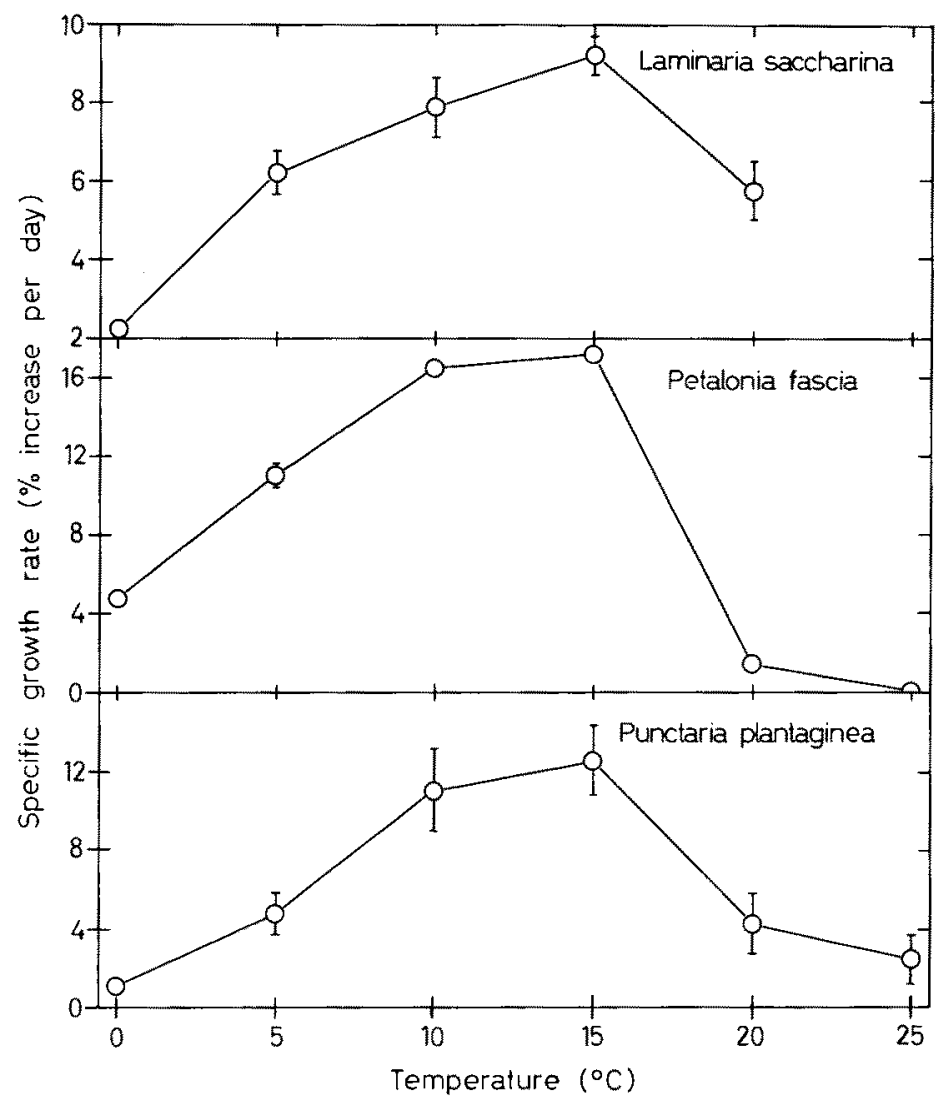

Fig. 4. Brown algae from the eulittoral (Petalonia fascia and Punctaria plantaginea) and sublittoral (Laminaria saccharina): growth vs. temperature plot

\section{DISCUSSION}

The temperature responses of the 21 species investigated reflect in part their latitudinal distribution. Of the species exhibiting a growth optimum at $10^{\circ} \mathrm{C}$ (Fig. 1), the southern limit of common occurrence along European coasts is NW Brittany in the cases of Desmarestia aculeata (van den Hoek \& Donze, 1967), Acrosiphonia arcta (Kornmann, 1962) and Phyllophora pseudoceranoides (Newroth, 1971). In contrast, the majority of the species exhibiting a broad optimum from $10-15^{\circ} \mathrm{C}$ (Figs 2-6) are, according to van den Hoek \& Donze (1967), common farther south on eastern Atlantic coasts, e. g. at about $46^{\circ} \mathrm{N}$ (Loire/Gironde: Fucus serratus, Cystoclonium purpureum, Membranoptera alata, Delesseria sanguinea), on the coast of NW Spain (Fucus vesiculosus, Ascophyllum nodosum, Laminaria saccharina, Plumaria elegans, Chondrus crispus, Dumontia incrassata), or even Morocco (Fucus spiralis, Petalonia fascia, Ceramium rubrum).

Of the species studied more in detail, Chondrus crispus and Ulva lactuca exhibited a broad growth optimum at $10-15^{\circ} \mathrm{C}$, with only a slight decrease at $20^{\circ} \mathrm{C}$. Similar results 


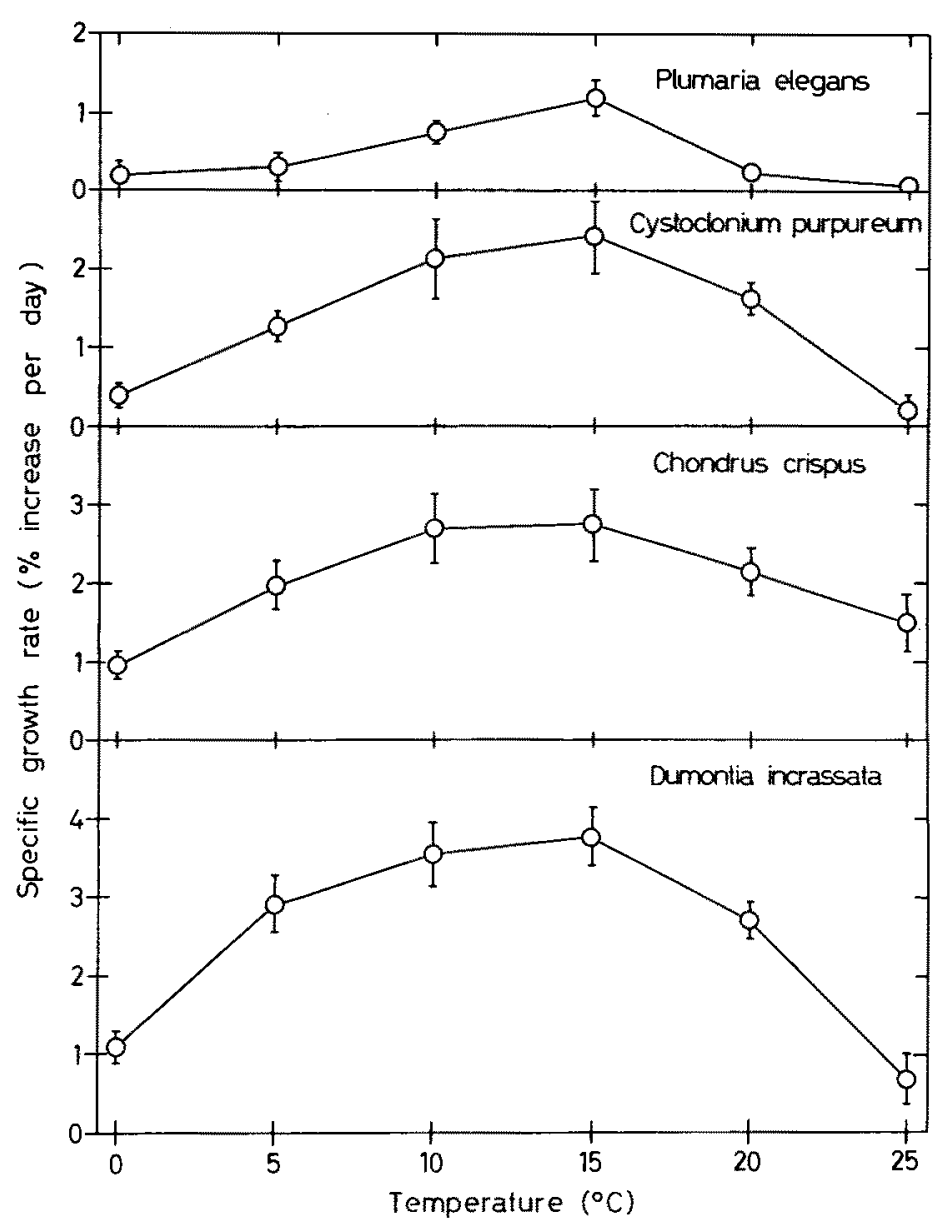

Fig. 5. Red algae from the lower eulittoral: growth vs. temperature plot

were obtained for Chondrus crispus from eastern Canada by Neish \& Fox (1971) and for both species by Enright (1979), although the latter author found the temperature optimum for growth of Canadian Ulva lactuca at $20^{\circ} \mathrm{C}$. The possible existence of thermal ecotypes cannot be ruled out especially in species which are regarded as cosmopolitan, and this problem deserves further experimental approaches. The Japanese species Ulva pertusa has its temperature optimum for growth at $20-25^{\circ} \mathrm{C}$ (Ohno, 1977). One also has to take into consideration that an alga might exhibit seasonal changes in requirement and tolerance of temperature, as is known for temperature resistance in higher plants (Larcher, 1975; Bannister, 1976). This possibility should be investigated e. g. in Porphyra umbilicalis which occurs all year round at Helgoland and which in the present study exhibited a growth optimum at $10^{\circ} \mathrm{C}$ for plants collected in spring (Fig. 1).

As in most of the species investigated in this study, the fronds of Laminaria saccharina grew fastest again at $10-15^{\circ} \mathrm{C}$, but growth rate at $20^{\circ} \mathrm{C}$ declined to about 


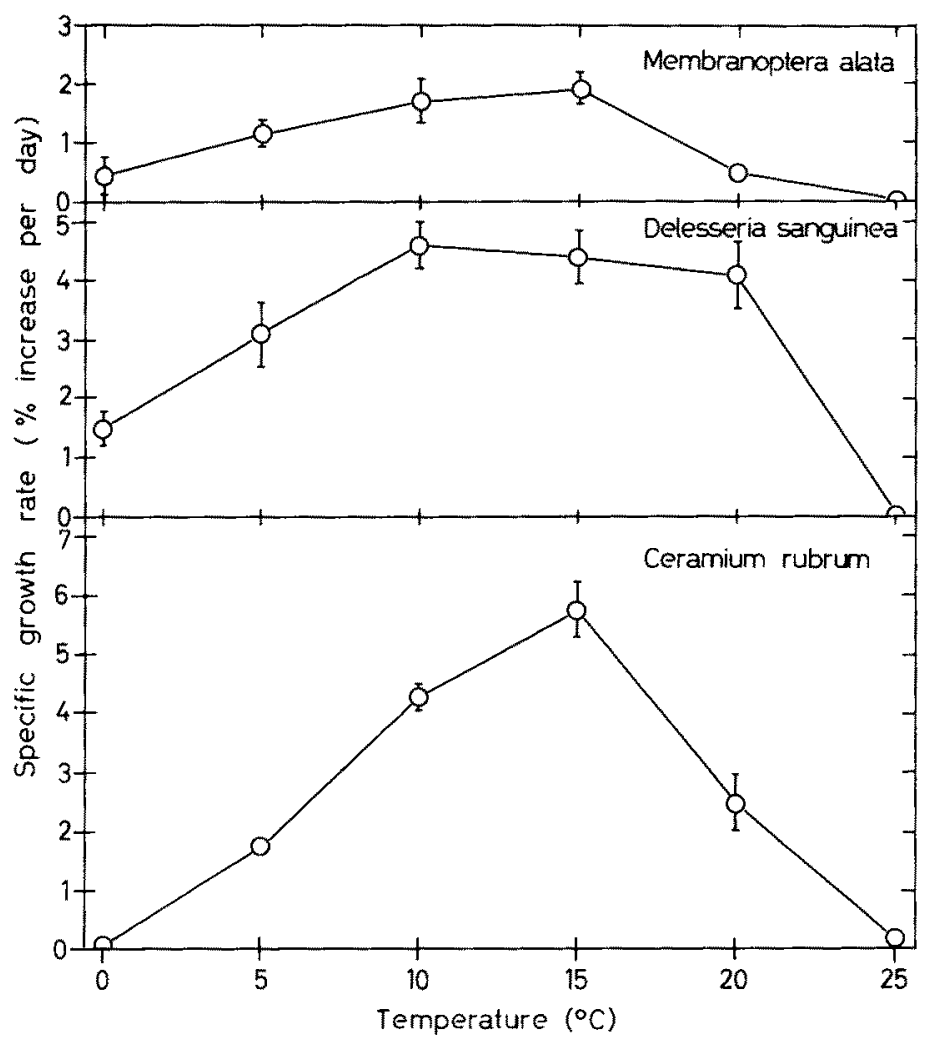

Fig. 6. Sublittoral red algae: growth vs. temperature plot

$50 \%$ of the value recorded at $15{ }^{\circ} \mathrm{C}$, and $25^{\circ} \mathrm{C}$ was lethal. The gametophytes of this species also have a broad temperature optimum for vegetative growth, ranging in this case from $10-20^{\circ} \mathrm{C}$ (Lüning, 1980). In European Laminaria saccharina the fact has been established that genetically differentiated formae with different blade morphology and tolerance towards high temperatures exist (Lüning, 1975; Lüning et al., 1978), and one may expect that the bullate Atlantic forma would not grow as well at $20^{\circ} \mathrm{C}$, as is evident in the case of the smooth forma from Helgoland (Fig. 4).

The light levels at which vegetative growth of adult thalli of macroscopic marine algae becomes saturated can be characterized in the following way (Lüning, 1980). In the eulittoral Fucales, which may be compared with higher "sun" plants, this light level occurs at $150-250 \mu \mathrm{E} \mathrm{m}^{-2} \mathrm{~s}^{-1}$. In the more bulky species of the upper sublittoral lightsaturation of growth occurs at 30-100, and in deep-water red algae at $10 \mu \mathrm{E} \mathrm{m} \mathrm{m}^{-2} \mathrm{~s}^{-1}$. The results obtained in the present study for Chondrus crispus from the lower eulittoral (also occurring in the upper sublittoral) and for Laminaria saccharina (upper sublittoral) fit into this scheme, since saturation of growth was found in both species above $70 \mu \mathrm{E} \mathrm{m}^{-2} \mathrm{~s}^{-1}$ (Fig. 7). The sheet-like eulittoral species Ulva lactuca or Porphyra umbilicalis (growth saturation above 70 or $30 \mu \mathrm{E} \mathrm{m}^{-2} \mathrm{~s}^{-1}$, respectively) obviously cannot be compared with the eulittoral fucalian "sun" plants, since the latter require considerably higher irradiances 


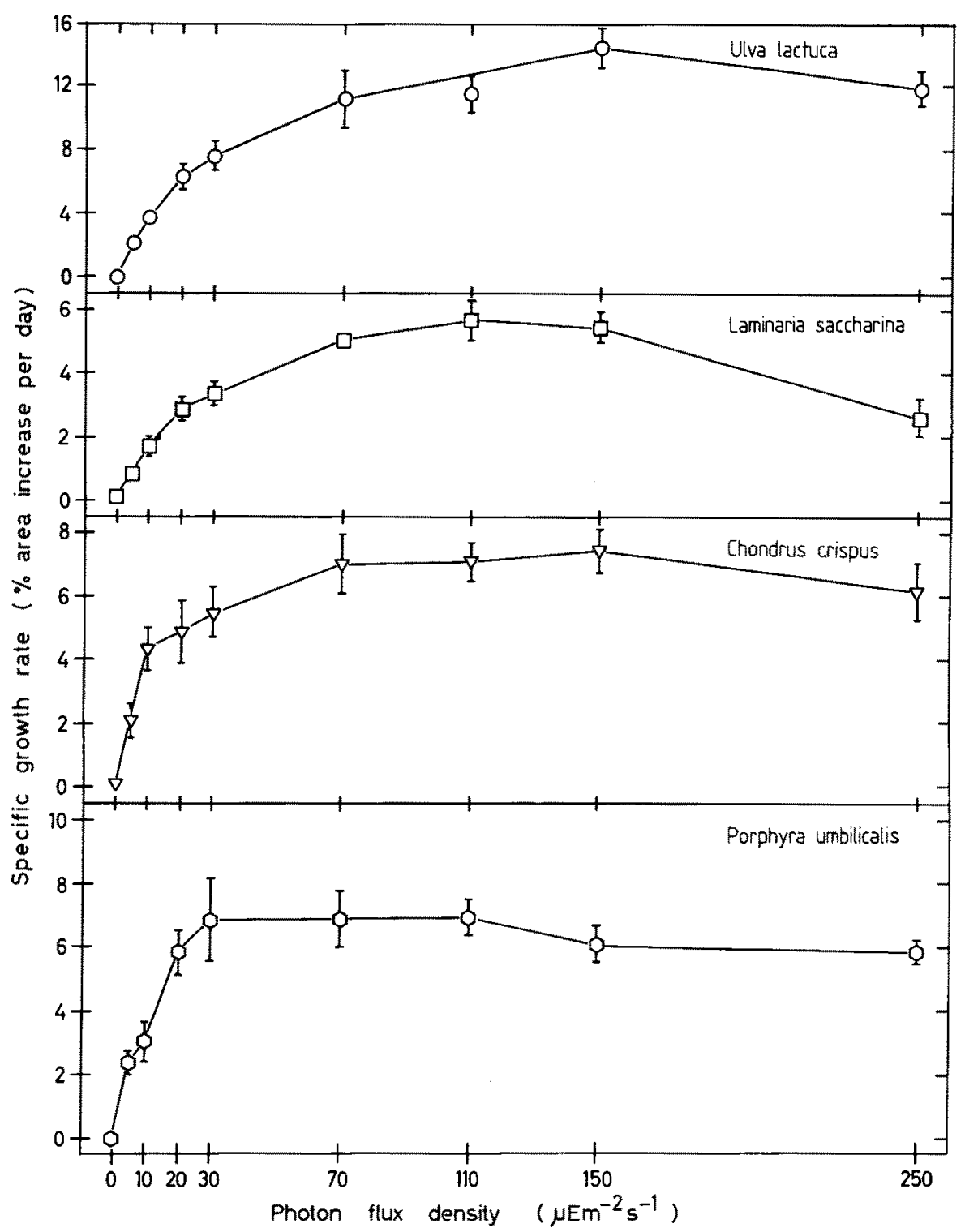

Fig. 7. Growth at different photon flux densities and in darkness

for growth saturation. This difference may partly reflect the differences in thallus thickness. When the flat thalli of Fucus spp. are irradiated only from one side, as during the growth experiments and as also may apply partly to the field conditions, the photosynthetic layer of the opposite, superficial photosynthetic layer can hardly contribute much to the overall photosynthetic rate due to low light transmission by the thick thallus so that the thick alga is "running at half power" under this condition. This is 
Table 2. Saturating photon flux densities (unit: $\mu \mathrm{E} \mathrm{m}^{-2} \mathrm{~s}^{-1}$ ) for growth and photosynthesis. Values in parentheses have been converted from original values of irradiance ( $\mathrm{W} \mathrm{m}^{-2}$ ) or illuminance (lux) by the formula given in "Materials and Methods"

\begin{tabular}{|lclcll|}
\hline \multicolumn{1}{|c}{ Species } & $\begin{array}{c}\text { Photo- } \\
\text { synthesis }\end{array}$ & Reference & Growth & Reference \\
\hline Ulva lactuca & $(200)^{*}$ & Yokohama (1973) & 70 & this study \\
Laminaria saccharina & 150 & Lüning (1979) & 70 & this study \\
Chondrus crispus & $120-260$ & Mathieson \& Norall (1975) & $(94)$ & Burns \& Mathieson (1972) \\
Porphyra umbilicalis & $(300)^{* *}$ & King \& Schramm 1976 & 30 & this study \\
& & & & \\
* This value relates to the eulittoral Japanese Ulva pertusa & \\
** This value relates to the eulittoral Baltic Porphyra leucosticta & \\
\hline
\end{tabular}

obviously in contrast to the situation in algae one or two cell layers thick, like Ulva spp. or Porphyтa spp.

As can be seen from Table 2, light-saturation of growth occurs at considerably lower irradiances than light-saturation of photosynthesis as determined by by short-term measurements. This was emphasized by McLachlan (1974) in the cases of Fucus dis-

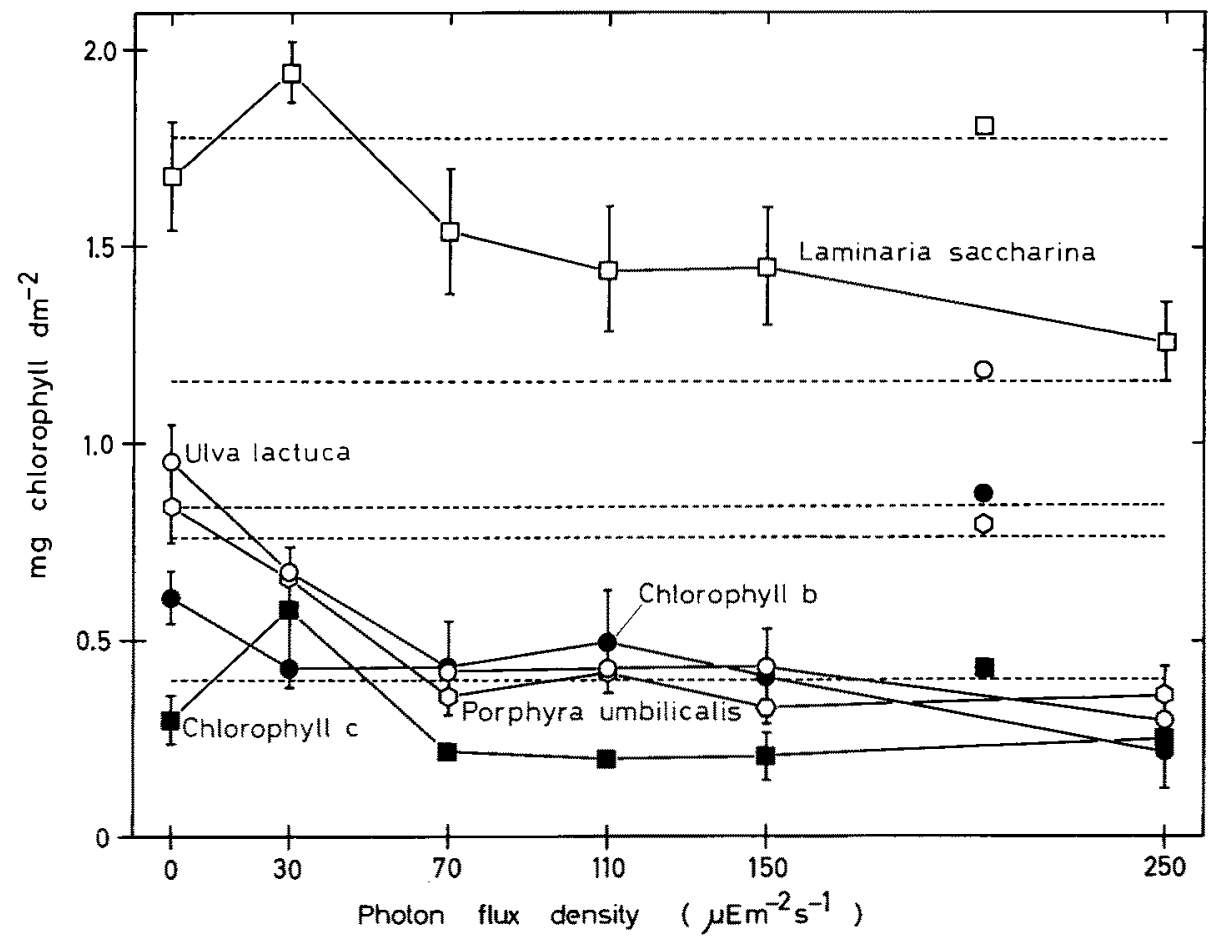

Fig. 8. Chlorophyll concentrations at different photon flux densities after 1 week. Broken lines indicate chlorophyll concentration at the start of the experiment. Chlorophyll $b$ in Ulva lactuca, chlorophyll $c$ in Laminaria saccharina, chlorophyll $a$ in all other cases 


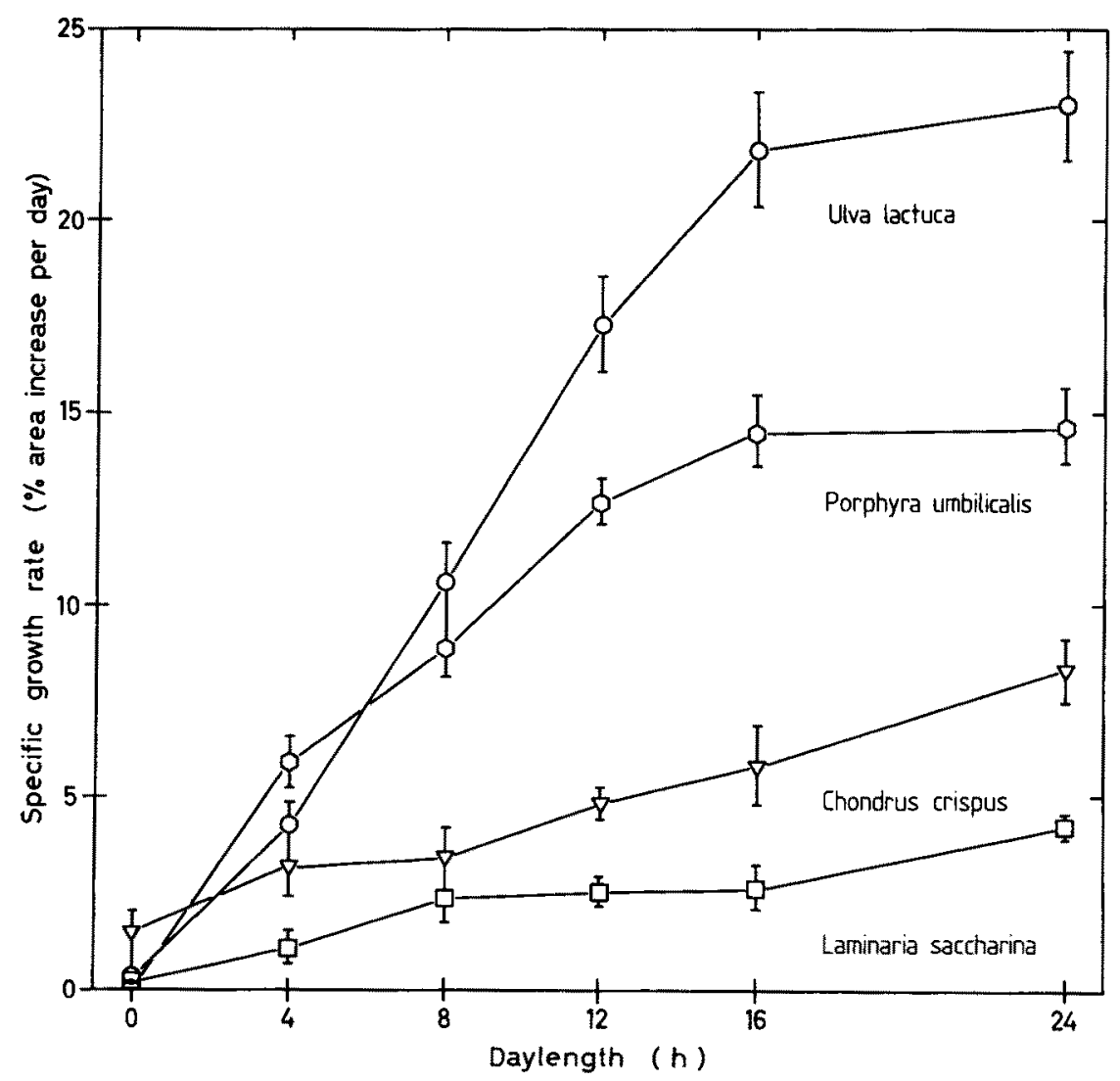

Fig. 9. Growth at different daylengths and in darkness

tichus, in which he found that the growth of embryos was light-saturated at $150 \mu \mathrm{E} \mathrm{m} \mathrm{m}^{-2} \mathrm{~s}^{-1}$ (30 $\left.\mathrm{Wm}^{-2}\right)$, i.e. at levels 3-4 times lower than required for short-time saturation of photosynthetic rate in Fucus spp. More such examples which are available from the recent literature (for references see Lüning, 1980) indicate that processes besides photosynthesis may limit growth. In this context it appears dangerous to extrapolate optimum irradiances for growth from short-term measurements of photosynthesis.

Only the sublittoral Laminaria saccharina showed a significant decrease of growth rate at the highest photon flux density employed $\left(250 \mu \mathrm{E} \mathrm{m}^{-2} \mathrm{~s}^{-1}\right.$, equivalent to $\left.50 \mathrm{~W} \mathrm{~m}^{-2}\right)$, whereas the other three species investigated, all from the eulittoral, were hardly inhibited by this photon flux density (Fig. 7). According to Biebl (1956), eulittoral algae, such as Ulva spp. and Porphyra spp., do not exhibit cytomorphological damage even if exposed to sunlight at an illuminance of $100000 \mathrm{lux}\left(400 \mathrm{~W} \mathrm{~m}^{-2}\right)$, although exposure time was only $1-2 \mathrm{~h}$ in the experiments of the author cited. For the sublittoral Laminaria hyperborea, Drew (1974) found that the photosynthetic rate was reduced to about $50 \%$ when the alga was brought near to the sea surface for $5 \mathrm{~h}$ at $250-300 \mathrm{~W}^{-2}$. The result obtained in the present study in artificial light for the growth rate of $L$. saccharina shows 
that during a long-term exposure irradiances 5 times lower may suppress growth rate significantly.

Chlorophyll content decreased at higher irradiances not only in the sublittoral $L$. saccharina, but also in the eulittoral Ulva lactuca and Porphyra umbilicalis. Reduction of pigment in strong light is a general phenomenon in higher plants (Egle, 1960; Björkman, 1973), as well as in phytoplankton (Harris, 1978), and a recent demonstration of this effect in various seaweeds has been achieved in field experiments by Ramus et al. (1976a, b). According to Harris (1978), in algae the greatest changes in the cellular content of chlorophyll occur in the range $50-100 \mu \mathrm{E} \mathrm{m}^{-2} \mathrm{~s}^{-1}$ (equivalent to about 2500-5000 lux in daylight or white fluorescent light). This range is also evident from the reactions of the presently investigated macroalgae, which exhibited the greatest decrease in chlorophyll a content at $30-70 \mu \mathrm{E} \mathrm{m}^{-2} \mathrm{~s}^{-1}$ (Fig. 8). The finding that this decrease was smallest in the relatively thick Laminaria saccharina may again be connected to the fact that the chloroplasts of the lower side of the plant, which was not exposed to the incident light, were protected from the light to a certain degree by the upper meristoderm and by the internal cell layers (which also contain chloroplasts, although only in small quantities), whereas in Ulva lactuca and Porphyra umbilicalis the majority of the chloroplasts were fully exposed to the incident light. The ratios of chlorophyll b/a (Ulva lactuca: 0.6-0.7) or c/a (Laminaria saccharina: 0.2-0.3) did not change significantly at the highest and lowest photon flux density of white fluorescent light used. This result is in accordance with the findings of Ramus et al. (1976b), who also did not detect remarkable changes in the ratio of the accessory pigments to chlorophyll $a$, when algae from sun and shade habitats within the intertidal zone were compared. However, this ratio increased with water depth, when algae were exposed at different levels in the sea (Ramus et al., 1976a, b; Ramus, 1978).

Continuous light provided best growth in Chondrus crispus as well as in Laminaria saccharina (Fig. 9), and this has also been found to be the case in Canadian C. crispus (Neish \& Fox, 1971), Codium fragile from Rhode Island (Hanisak, 1979), and in Ascophyllum nodosum and Fucus serratus from Norway (Strömgren, 1978). However, for several other algae daylength saturation is known to occur, as was the case in Ulva lactuca and Porphyra umbilicalis for which the growth rate did not increase at daylengths longer than $16 \mathrm{~h}$ light per day. Daylength saturation takes place in Pelvetia canaliculata and $F$. spiralis at daylengths longer than $18 \mathrm{~h}$ (Strömgren, 1978), and in the green algae Mougeotia sp. (Neuscheler-Wirth, 1970) or Acetabularia crenulata (Terborgh \& Thimann, 1964) at daylengths exceeding $12 \mathrm{~h}$ light per day, provided that the algae are irradiated with growth-saturating irradiances. The reasons for the differential growth behaviour of the species towards daylength are unknown. It may be expected that, as in unicellular algae (Sournia, 1974; Harris, 1978; Nelson \& Brand, 1979), the role of the light-dark cycle in regulation and synchronization of cell division and of various other processes connected with growth, as well as interference of photoperiod with diel periodicity might be decisive. Among seaweeds circadian rhythms have recently been demonstrated to occur in Ulva lactuca in regard to chloroplast orientation (Britz \& Briggs, 1976; Britz et al., 1976).

Acknowledgement. M.D.F. wishes to express his thanks to the Deutscher Akademischer Auslandsdienst for a grant to work at the Biologische Anstalt Helgoland. 


\section{LITERATURE CITED}

Arnon, D. I., 1949. Copper enzymes in isolated chloroplasts. Polyphenoloxidase in Beta vulgaris. Pl. Physiol., Lancaster 24, 1-15.

Bannister, P., 1976. Introduction to physiological plant ecology. Blackwell, Oxford, $273 \mathrm{pp}$.

Biebl, R., 1956. Lichtresistenz von Meeresalgen. - Protoplasma 46, 63-89.

Biebl, R., 1958. Temperatur- und osmotische Resistenz von Meeresalgen der bretonischen Küste. Protoplasma 50, 217-242.

Biebl, R., 1962. Temperaturresistenz tropischer Meeresalgen (verglichen mit jener von Algen in temperierten Meeresgebieten). - Botanica mar. 4, 241-254.

Björkman, O., 1973. Comparative studies on photosynthesis in higher plants. In: Photophysiology. Ed. by A. C. Giese. Acad. Press, New York, 8, 1-63.

Britz, S. J. \& Briggs, W. R., 1976. Circadian rhythms of chloroplast orientation and photosynthetic capacity in Ulva. - Pl. Physiol., Lancaster 58, 22-27.

Britz, S. J., Pfau, J., Nultsch, W. \& Briggs, W. R., 1976. Automatic monitoring of a circadian rhythm of change in light transmittance in UIva. - Pl. Physiol, Lancaster 58, 17-21.

Burns, R. L. \& Mathieson, A. C., 1972. Ecological studies of economic red algae. II. Culture studies of Chondrus crispus Stackhouse and Gigartina stellata (Stackhouse) Batters. - J. exp. mar. Biol, Ecol. 8, 1-6.

Drew, E. A., 1974. Light inhibition of photosynthesis in macro-algae. - Brit. phycol. J. 9, 217-218.

Egle, K., 1960. Menge und Verhältnis der Pigmente. In: Encyclopedia of plant physiology. Vol V: The assimilation of carbon dioxide. P. 1. Ed. by W. Ruhland. Springer, Berlin, 444-496.

Enright, C. T., 1979. Competitive interaction between Chondrus crispus (Florideophyceae) and Ulva lactuca (Chlorophyceae) in Chondrus aquaculture. - Int. Seaweed Symp. 9, 209-218.

Evans, G. C., 1972. The quantitative analysis of plant growth. Studies in ecology. Blackwell, Oxford, $1,1-734$.

Gessner, F., 1970. Temperature: Plants. In: Marine ecology. Ed. by O. Kinne. Wiley-Interscience, London, $1(1), 363-406$.

Hanisak, M. D., 1979. Growth patterns of Codium fragile spp. tomentoides in response to temperature, irradiance, salinity, and nitrogen source. - Mar. Biol. 50, 319-332.

Harris, G. P., 1978. Photosynthesis, productivity and growth: the physiological ecology of phytoplankton. - Arch. Hydrobiol. (Beih.: Ergebn. Limnol.) 10, 1-171.

Hoek, C. van den, 1975. Phytogeographical provinces along the coasts of the northern Atlantic Ocean. - Phycologia 14, 317-330.

Hoek, C. van den, 1979. The phytogeography of Cladophora (Chlorophyceae) in the northern Atlantic Ocean, in comparison to that of other benthic algal species. - Helgoländer wiss. Meeresunters. 32, 374-393.

Hoek, C. van den \& Donze, M., 1967. Algal phytogeography of the European Atlantic coasts. Blumea 15, 63-89.

King, R. J. \& Schramm, W., 1976. Photosynthetic rates of benthic marine algae in relation to light intensity and seasonal variation. - Mar. Biol. 37, 215-222.

Kornmann, P., 1962. Eine Revision der Gattung Acrosiphonia. - Helgoländer wiss. Meeresunters. 8 , 219-292.

Larcher, W., 1975. Physiological plant ecology. Springer, New York, 252 pp.

Lüning, K., 1975. Kreuzungsexperimente an Laminaria saccharina von Helgoland und von der Isle of Man. - Helgoländer wiss. Meeresunters. 27, 108-114.

Lüning, K., 1979. Growth strategies of three Laminaria species (Phaeophyceae) inhabiting different depth zones in the sublittoral region of Helgoland (North Sea). - Mar. Ecol. Prog. Ser. 1, 195-207.

Lüning, K., 1980. Light. In: The biology of seaweeds. Ed. by C. S. Lobban \& M. J. Wynne. Blackwell, Oxford (in press).

Lüning, K., Chapman, A. R. O. \& Mann, K. H., 1978. Crossing experiments in the non-digitate complex of Laminaria from both sides of the Atlantic. - Phycologia 17, 293-298.

Mathieson, A. C. \& Norall, T. L., 1975. Photosynthetic studies of Chondrus crispus.-Mar. Biol. 33, $207-213$. 
McLachlan, J., 1974. Effects of temperature and light on growth and development of embryos of Fucus edentatus and $F$. distichus ssp. distichus. - Can. J. Bot. 52, 943-951.

Neish, A. C. \& Fox, C. H., 1971. Greenhouse experiments on the vegetative propagation of Chondrus crispus. - Tech. Rep. Atl. reg. Lab. natn Res. Counc. Can., Halifax, N. S. 12.

Nelson, D. M. \& Brand, L. E., 1979. Cell division periodicity in 13 species of marine phytoplankton on a light: dark cycle. - J. Phycol. 15, 67-75.

Neuscheler-Wirth, H., 1970. Wachstumsgeschwindigkeit und Wachstumsrhythmik bei Mougeotia. - Z. Pflanzenphysiol. 63, 352-396.

Newroth, P. R., 1971. The distribution of Phyllophora in the North Atlantic and Arctic regions. Can. J. Bot. 49, 1017-1024.

Ohno, M., 1977. Effect of temperature on the growth rate of seaweeds in an aquatron culture system. - Bull. Jap. Soc. Phycol. 25, 257-263.

Ramus, J., 1978. Seaweed anatomy and photosynthetic performance: the ecological significance of light guides, heterogenous absorption and multiple scatter. - J. Phycol. 14, 352-362.

Ramus, J., Beale, S. I. \& Mauzerall, D., 1976a. Correlation of changes in pigment content with photosynthetic capacity of seaweeds as a function of water depth. - Mar. Biol. 37, 231-238.

Ramus, J., Beale, S. I., Mauzerall, D. \& Howard, K. L., 1976b. Changes in photosynthetic pigment concentration in seaweeds as a function of water depth. - Mar. Biol. 37, 223-229.

Setchell, W. A., 1915. The law of temperature connected with distribution of marine algae. - Ann. Mo. bot. Gdn 2, 287-305.

Setchell, W. A., 1920. The temperature interval in the geographical distribution of marine algae. Science, N. Y. 53, 187-190.

Sournia, A., 1974. Circadian periodicities in natural populations of marine phytoplankton. - Adv. mar. Biol. 12, 325-389.

Strömgren, T., 1978. The effect of photoperiod on the length growth of five species of intertidal Fucales. - Sarsia 63, 155-158.

Terborgh, J. \& Thimann, K., 1964. Interaction between daylength and light intensity in the growth and chlorophyll content of Acetabularia crenulata. - Planta 63, 83-98.

Wasley, J. W. F, Scott, W. T. \& Holt, A. S., 1970. Chlorophyllides c. - Can. J. Biochem. 48, 376-383.

Yokohama, Y., 1973. Photosynthetic properties of marine benthic green algae from different depths in the coastal area. - Bull. Jap. Soc. Phycol. 21, 70-75. 